\title{
Decreased BDNF levels in amygdala and hippocampus after intracerebroventricular administration of ouabain
}

\author{
Diminuição dos níveis de BDNF em amígdala e hipocampo após a administração intracerebroventricular de \\ ouabaína \\ Luciano K. Jornada ${ }^{1}$, Samira S. Valvassori ${ }^{1}$, Wilson R. Resende ${ }^{1}$, Morgana Moretti ${ }^{1}$, Camila L. Ferreira ${ }^{1}$, \\ Gabriel R. Fries², Flavio Kapczinshi², JoÃo Quevedo1,3
}

1 Laboratory of Neurosciences and National Science and Technology Institute for Translational Medicine and Center of Excellence in Applied Neurosciences of Santa Catarina (NENASC), Postgraduate Program in Health Sciences, Health Sciences Unit, University of Southern Santa Catarina, SC, Brazil.

2 Bipolar Disorders Program, Laboratory of Molecular Psychiatry and National Science and Technology Institute for Translational Medicine, Federal University of Rio Grande do Sul (UFRGS), Porto Alegre, RS, Brazil.

${ }^{3}$ Laboratory of Translational Psychiatry, Research Center, São José Hospital, Criciúma, SC, Brazil.

Received: 4/3/2012 - Accepted: 9/21/2012

\begin{abstract}
Objective: The present study aims to investigate the effects of ouabain intracerebroventricular injection on BDNF levels in the amygdala and hippocampus of Wistar rats. Methods: Animals received a single intracerebroventricular injection of ouabain $\left(10^{-3}\right.$ and $\left.10^{-2} \mathrm{M}\right)$ or artificial cerebrospinal fluid and immediately, $1 \mathrm{~h}, 24 \mathrm{~h}$, or seven days after injection, BDNF levels were measured in the rat's amygdala and hippocampus by sandwich-ELISA ( $\mathrm{n}=8$ animals per group). Results: When evaluated immediately, $3 \mathrm{~h}$, or $24 \mathrm{~h}$ after injection, ouabain in doses of $10^{-2}$ and $10^{-3} \mathrm{M}$ does not alter BDNF levels in the amygdala and hippocampus. However, when evaluated seven days after injection, ouabain in $10^{-2}$ and $10^{-3} \mathrm{M}$, showed a significant reduction in BDNF levels in both brain regions evaluated. Discussion: In conclusion, we propose that the ouabain decreased BDNF levels in the hippocampus and amygdala when assessed seven days after administration, supporting the $\mathrm{Na} / \mathrm{K}$ ATPase hypothesis for bipolar illness.
\end{abstract}

Jornada LK, et al. / Rev Psiq Clín. 2012;39(5):157-60

Keywords: BDNF, mania, Na/K ATPase, ouabain.

\section{Resumo}

Objetivo: O presente estudo tem como objetivo investigar os efeitos da injeção intracerebroventricular de ouabaína sobre os níveis de BDNF na amígdala e no hipocampo de ratos Wistar. Métodos: Os animais receberam uma única injeção intracerebroventricular de ouabaína (10-3 and $10^{-2} \mathrm{M}$ ) ou fluido cerebroespinhal artificial e, imediatamente, 3h, 24h ou sete dias após a injeção, os níveis de BDNF foram mensurados na amígdala e hipocampo dos ratos por ELISA sandwich (n $=8$ animais por grupo). Resultados: Quando avaliados imediatamente após a injeção, 3 h ou $24 \mathrm{~h}$, ouabaína nas doses $10^{-2}$ e $10^{-3} \mathrm{M}$ não alterou os níveis de BDNF em ambas as estruturas avaliadas. Entretanto, quando avaliados sete dias após a injeção, ouabaína nas doses $10^{-2}$ e $10^{-3} \mathrm{M}$ mostrou uma significante redução nos níveis de BDNF em amígdala e hipocampo. Conclusão: Em conclusão, propõe-se que a administração de ouabaína diminuiu os níveis de BDNF em amígdala e hipocampo quando avaliados sete dias após a injeção, suportando a hipótese da participação da Na/K ATPase no transtorno bipolar.

Jornada LK, et al. / Rev Psiq Clín. 2012;39(5):157-60

Palavras-chave: BDNF, mania, Na/K ATPase, ouabaína.

\section{Introduction}

Bipolar disorder (BD) is a prevalent, highly disabling, and chronic mood disorder, characterized by the presence of manic and depressive symptoms, but, the key clinical factor of the bipolar condition is a manic episode, characterized by an extremely elevated mood, energy, psychomotor activation, and sometimes psychosis. This is a disease with unclear pathophysiology and pathogenesis.

Sodium and potassium-activated adenosine triphosphatase $(\mathrm{Na} / \mathrm{K}$ ATPase) plays an important role in regulating neural activity and neurotransmitter release ${ }^{1-7}$. Several studies have found direct and indirect evidence for a mood-state related decrease in the activity of the $\mathrm{Na} / \mathrm{K}$ ATPase or Na pump in bipolar illness ${ }^{8}$. This change can directly alter neuronal activity ${ }^{9}$ and may be associated with activation of a second message in the absence of a first message (neurotransmitter) ${ }^{10}$. The small reduction in sodium pump activity may alter the excitability of neurons and produces symptoms like-mania behavior, such as hyperactivity, aggressiveness, and risk-taking behavior ${ }^{9,11,12}$.

In more recent studies, BD has been associated with impairments in neuroplasticity and cell survival. Brain-derived neurotrophic fac- tor (BDNF) is a member of the nerve growth factor family and has involvement in promoting synaptic efficacy, neuronal connectivity and neuroplasticity ${ }^{13}$, being highly expressed in brain areas that are known to regulate cognitive and emotional behavior, such as the hippocampus and amygdala ${ }^{14}$. BDNF regulates neuronal development and survival, and controls the activity of many neurotransmitters, including the serotoninergic, dopaminergic, and glutamatergic systems ${ }^{15}$. Studies support the notion that changes in BDNF levels may be involved in the pathophysiology of $\mathrm{BD}^{16,17}$. Several studies show that serum BDNF is decreased during manic and depressive episodes ${ }^{16-21}$.

It is known that the intracerebroventricular (ICV) injection of ouabain (OUA), a potent $\mathrm{Na} / \mathrm{K}$ ATPase pump inhibitor, induces hyperlocomotion 22,23 , which may persist for several days after a single injection ${ }^{24}$. Thus, the present study aims to investigate the effects of ICV administration of OUA in rats on BDNF expression in the hippocampus and amygdala immediately, $1 \mathrm{~h}$, or $24 \mathrm{~h}$, to mimic an acute episode of mania, and seven days, to mimic the persistence of a manic episode, after ouabain injection. 


\section{Methods}

\section{Animals}

We conducted the study using 96 ( $\mathrm{n}=8$ animals per group) adult male Wistar rats (250-300 g - approximately 2 months of age) obtained from our breeding colony. The animals were housed 5 to a cage, on a 12-hour light/dark cycle (lights on at 7:00 am), with free access to food and water. All experimental procedures were carried out in accordance with the National Institutes of Health Guide for the Care and Use of Laboratory Animals and the Brazilian Society for Neuroscience and Behaviour ( $\mathrm{SBNeC})$. This study was approved by the local ethics committee (Comitê de Ética em Uso de Animais da Universidade do Extremo Sul Catarinense, Protocol n ${ }^{\circ}$ 536/2007), and all efforts were made to minimize animal suffering, to reduce the number of animals used, and to utilize alternatives to in vivo techniques.

\section{Surgical procedure and treatment}

Animals were intraperitoneally anesthetized with ketamine $(80 \mathrm{mg} /$ $\mathrm{kg}$ ) and xylasine $(10 \mathrm{mg} / \mathrm{kg})$. In a stereotaxic apparatus, the skin of the rat skull was removed and a 27 gauge $9 \mathrm{~mm}$ guide cannula was placed at $0.9 \mathrm{~mm}$ posterior to bregma, $1.5 \mathrm{~mm}$ right from de midline and $1.0 \mathrm{~mm}$ above the lateral brain ventricle. Through a $2 \mathrm{~mm}$ hole made at the cranial bone, a cannula was implanted $2.6 \mathrm{~mm}$ ventral to the superior surface of the skull, and fixed with jeweler acrylic cement. Animals were tested on the third day following surgery. A 30 gauge cannula was fitted into the guide cannula and connected by a polyethylene tube to a microsyringe. The tip of the infusion cannula protruded $1.0 \mathrm{~mm}$ beyond the guide cannula aiming the right lateral brain ventricle. Each animal was administered $5 \mu \mathrm{l}$ of either artificial cerebrospinal fluid (aCSF) or OUA $\left(10^{-3}\right.$ and $10^{-2} \mathrm{M}$; Sigma Chemical, Saint Louis, USA; dissolved in aCSF), over $30 \sec ^{23,25}$.

\section{Locomotor activity}

Locomotor activity was measured immediately after (10 minutes approximately), $3 \mathrm{~h}, 24 \mathrm{~h}$ or seven days after ouabain or aCSF injection. Locomotor activity was assessed using the open-field task as previously described ${ }^{26}$. This task was performed in a $40 \times 60 \mathrm{~cm}$ open field surrounded by $50 \mathrm{~cm}$ high walls, made of brown plywood, with the floor divided into 12 equal rectangles by black lines. The animals were gently placed on the left rear rectangle, and left free to explore the arena for $5 \mathrm{~min}$. Crossings of the black lines (locomotor activity/ horizontal activity) was counted.

\section{BDNF levels measurement}

BDNF levels in hippocampus and amygdala were measured immediately after (10 minutes approximately), 3h, 24h or seven days after ouabain or aCSF injection by anti-BDNF sandwich-ELISA, according to the manufacturer instructions (Chemicon, USA). Briefly, brain slices were homogenized in phosphate buffer solution (PBS) with 1 $\mathrm{mM}$ phenylmethylsulfonyl fluoride (PMSF) and $1 \mathrm{mM}$ ethylene glycol tetraacetic acid (EGTA). Microtiter plates (96-well flat-bottom) were coated for $24 \mathrm{hr}$ with the samples diluted 1:2 in sample diluent and standard curve ranged from 7.8 to $500 \mathrm{pg} / \mathrm{ml}$ of BNDF. The plates were then washed four times with sample diluent and a monoclonal anti-BNDF rabbit antibody diluted 1:1000 in sample diluent was added to each well and incubated for $3 \mathrm{hr}$ at room temperature. After washing, a peroxidase conjugated anti-rabbit antibody (diluted 1:1000) was added to each well and incubated at room temp room temperature for $1 \mathrm{~h}$. After addition of streptavidin-enzyme, substrate and stop solution, the amount of BDNF was determined by absorbance in $450 \mathrm{~nm}$. The standard curve demonstrates a direct relationship between Optical Density (OD) and BDNF concentration. Total protein was measured by Lowry's method using bovine serum albumin as a standard.

\section{Statistical analysis}

Data are presented as mean and standard error of the mean. Differences among the experimental groups were determined by one-way analysis of variance (ANOVA) followed by the Tukey post-hoc test. In all comparisons, statistical significance was set at $P<0.05$.

\section{Results}

Results for locomotor activity are shown in figure 1. When evaluated immediately, $3 \mathrm{~h}, 24 \mathrm{~h}$ or seven days after ICV injection, the ouabain $\left(10^{-2}\right.$ and $\left.10^{-3} \mathrm{M}\right)$ administration increased rat spontaneous locomotion, compared to the control group.

As illustrated in figure 2 , when evaluated immediately, $1 \mathrm{~h}, 3 \mathrm{~h}$, or $24 \mathrm{~h}$ after ICV injection, ouabain in doses of $10^{-2}$ and $10^{-3} \mathrm{M}$ does not alter BDNF levels in both the amygdala and hippocampus. However, when evaluated seven days after ICV injection (Figure 2D), ouabain in doses of $10^{-2}$ and $10^{-3} \mathrm{M}$, showed a significant reduction in the BDNF levels in the amygdala and hippocampus.

\section{Discussion}

The $\mathrm{Na} / \mathrm{K}$ ATPase (Na pump) maintains the concentration gradients of $\mathrm{Na}$ and $\mathrm{K}$ ions across the surface membrane of animal cells. It has been proposed that the ICV administration of ouabain in rats induces the neuronal ATPase hypoactivity, which is proposed to occur in mania and depression in humans. Previous studies showed that the ICV injection of ouabain induces hyperlocomotion (manic-like behavior), which persist for seven days after a single injection ${ }^{25,27}$, suggesting that inhibition of brain $\mathrm{Na} / \mathrm{K}$ ATPase activity causes hyperactivity. We also demonstrated that when evaluated immediately, $3 \mathrm{~h}, 24 \mathrm{~h}$ or seven days after ICV injection, the ouabain administration increased rat spontaneous locomotion.

In the present study, we demonstrate that ouabain does not alter BDNF levels in the hippocampus and amygdala when evaluated immediately after a single ICV injection. Inhibition of $\mathrm{Na} / \mathrm{K}$ ATPase induces alterations in intracellular ion concentrations, which can induce secondary changes in the activity of intracellular signal pathways ${ }^{28}$. However, these changes can occur in a late time course, as observed in the evaluation seven days following the injection. Moreover, BDNF protein levels may not be altered immediately after an ICV ouabain injection because synthesis or degradation of BDNF takes time. In this evaluation, we showed that ouabain causes a substantial reduction in BDNF levels of both structures in $10^{-2}$ and $10^{-3} \mathrm{M}$ doses, when assessed seven days after administration. Previous studies from our research laboratory showed that after seven days the ouabain administration causes damage to lipids and proteins in the rat brain, but not immediately after ouabain administration ${ }^{25,29}$. Whereas acute reactions to ouabain in animals have considerable homology to a manic episode (as reduction in the $\mathrm{Na} / \mathrm{K}$ ATPase and consequent hyperactivity), the persistent effect of ouabain resembles aspects of illness progression. From these observations we suggest that ICV administration of ouabain is a good model to study the chronicity of BD.

Palomino et al., in a study with bipolar patients that experienced a first psychotic episode, observed a dramatic decrease in levels of plasma BDNF of the patients ${ }^{30}$. Interestingly, BDNF levels in all instances progressively increased towards control values during 1-year follow-up subsequent to the first episode ${ }^{31}$, which should be related to the neuroprotective effect of the treatment used in this disease.

A growing body of evidence has showed that the pathophysiology of BD could be the result of deregulation of synaptic plasticity with downstream alterations of neurotrophins ${ }^{31}$. Neuroimaging studies suggest that decreased BDNF levels may account for structural brain changes in bipolar patients ${ }^{32,33}$. Kapczinski et al. ${ }^{17}$ recently showed that serum levels of BDNF are decreased during both manic and depressive mood episodes, being normalized in euthymia. Moreover, acute treatments with psichostimulant drugs, such as amphetamine, decrease BDNF levels in rat cerebral tissues accompanied with hyperlocomotion ${ }^{26}$.

This study presents the following limitations: a) this animal model mimics only aspects of manic episodes and b) only evaluated BDNF levels in the brain of rats, however it is known that other neurotrophins (NT-3, NT-4 and NGF) ${ }^{34-36}$ and other biochemical changes (oxidative protein, lipid and DNA damage) ${ }^{37,38}$ are involved in aspects of $\mathrm{BD}$ progression. 

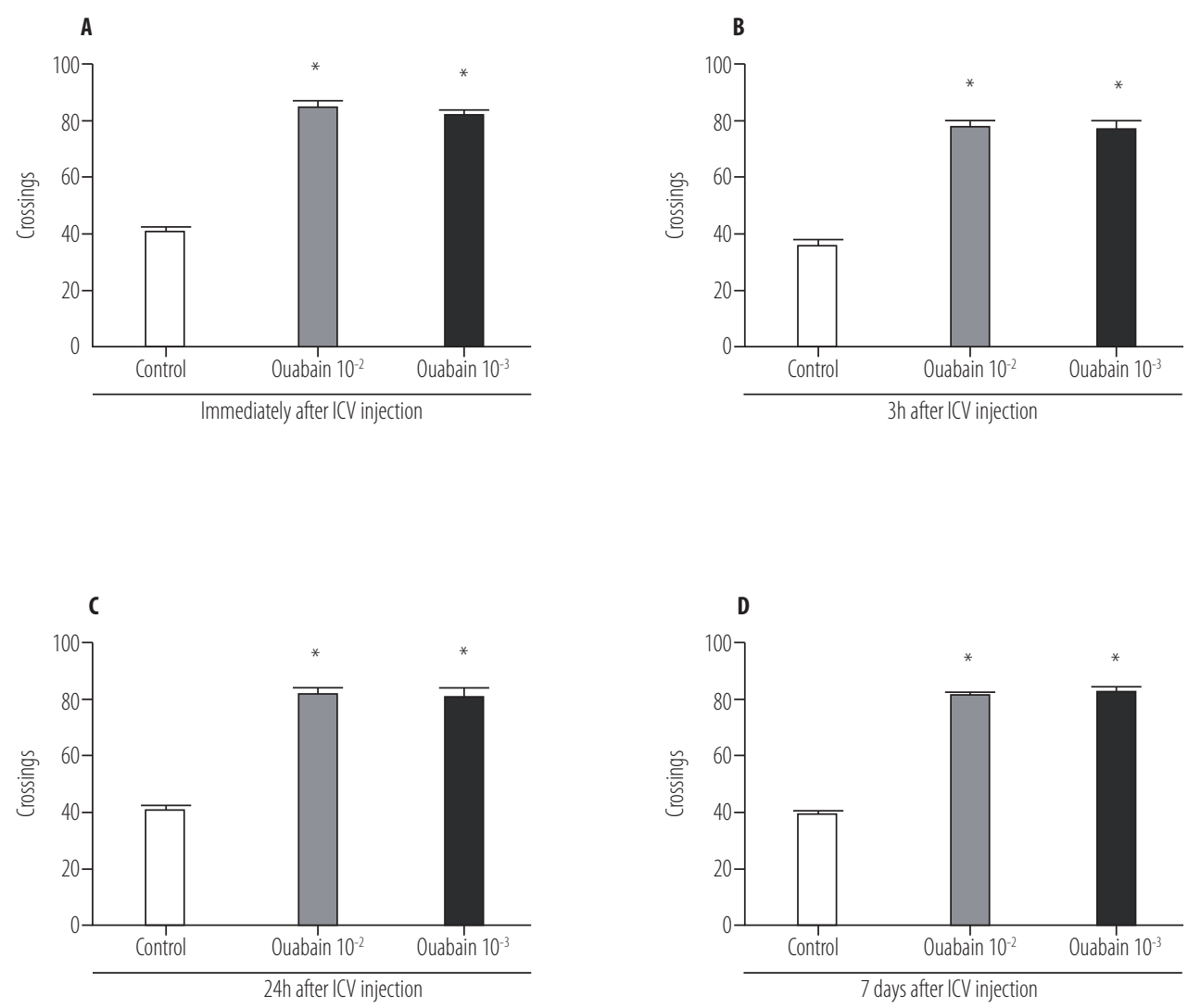

Figure 1. Locomotor activity immediately (A), 3h (B), 24h (C) or seven days (D) after ouabain or aCSF ICV injection. Bars represent means \pm standard error of means of 7 animals. ${ }^{*} P<0.05$ vs. aCSF group, according to ANOVA followed by the Tukey test.
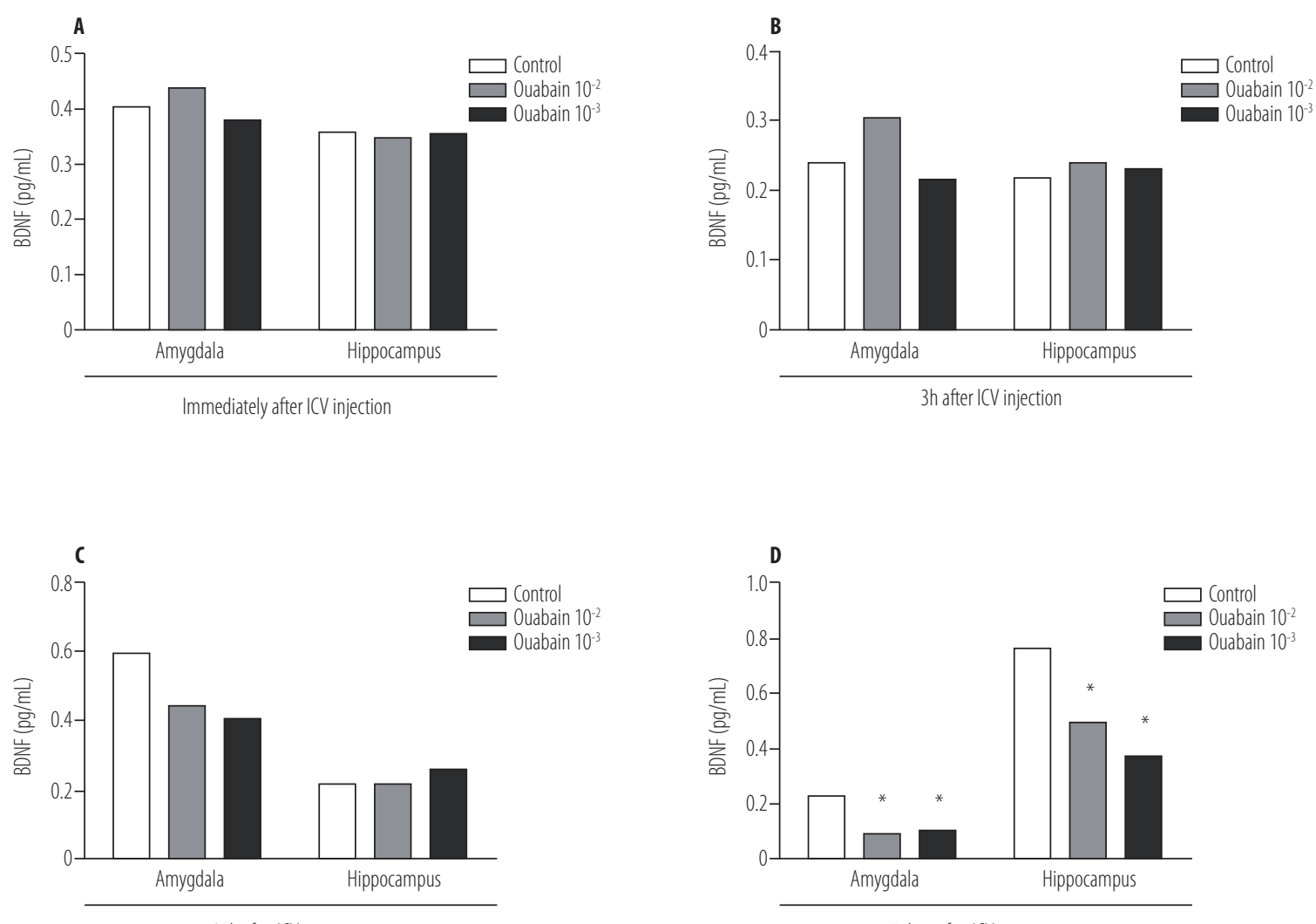

24h after ICV injection

7 days after ICV injection

Figure 2. BDNF levels in rat hippocampus and amygdala immediately (A), 3h (B), 24h (C) or seven days (D) after ouabain or aCSF ICV injection. Bars represent means \pm standard error of means of 7 animals. ${ }^{*} P<0.05$ vs. aCSF group, according to ANOVA followed by the Tukey test. 


\section{Conclusion}

Impairment of brain $\mathrm{Na} / \mathrm{K}$ ATPase has an important role in the pathogenesis of $\mathrm{BD}$ and these findings suggest the possible link between $\mathrm{BDNF}$ and $\mathrm{Na} / \mathrm{K}$ ATPase induced by ouabain in rats. Our findings support the $\mathrm{Na} / \mathrm{K}$ ATPase hypothesis for bipolar illness, but, further studies must be conducted to define the model, explore its utility in understanding bipolar illness and in potential drug screening.

\section{Acknowledgements}

We thank CNPq, Fapesc, Capes and Unesc for financial support.

\section{Sources of funding}

This research was supported by grants from CNPq (FK and JQ), Fapesc (JQ), Instituto Cérebro e Mente (JQ) and Unesc (JQ). FK and JQ are CNPq Research Fellow. MM and SSV are holders of Capes studentships, COA and CLF is holder of a CNPq Studentship.

\section{Conflicts of interest}

Prof. Quevedo has received grant/research support from $\mathrm{CNPq}$, Capes, Fapesc and Unesc and has been a member of the speakers' boards for Eli Lilly. Prof. Kapczinski has received speaker fees, educational grants and travel assistance from Eli Lilly.

\section{References}

1. Vaillend C, Mason SE, Cuttle MF, Alger BE. Mechanisms of neuronal hyperexcitability caused by partial inhibition of $\mathrm{Na}+-\mathrm{K}+$-ATPases in the rat CA1 hippocampal region. J Neurophysiol. 2002;88:2963-78.

2. Vatta M, Pena C, Fernandez BE, Rodriguez G, De Lores Arnaiz E. Endobain $\mathrm{A}$ brain $\mathrm{Na}+, \mathrm{K}+$-ATPase inhibitor, decreases norepinephrine uptake in rat hypothalamus. Life Sci. 2004;76:359-65.

3. Vizi ES. Termination of transmitter release by stimulation of sodiumpotassium activated ATPase. J Physiol. 1977;267:261-80.

4. Vizi ES. Na+-K+-activated adenosinetriphosphatase as a trigger in transmitter release. Neuroscience. 1978;3:367-84.

5. Vizi ES, Tŏrŏk T, Seregi A, Serfŏzŏ P, Adam-Vizi V. Na-K activated ATPase and the release of acetylcholine and noradrenaline. J Physiol. 1982;78:399-406.

6. Vizi ES, Vyskocil F. Changes in total and quantal release of acetylcholine in the mouse diaphragm during activation and inhibition of membrane ATPase. J Physiol. 1979;286:1-14.

7. Moseley AE, Williams MT, Schaefer TL, Bohanan CS, Neumann JC, Behbehani MM, et al. Deficiency in Na,K-ATPase alpha isoform genes alters spatial learning, motor activity, and anxiety in mice. J Neurosci. 2007;27:616-26.

8. Christo PJ, El-Mallakh S. Possible role of endogenous ouabain-like compounds in the pathophysiology of bipolar illness. Med Hypotheses. 1993;41:378-83.

9. El-Mallakh RS, Wyatt RJ. The Na,K-ATPase hypothesis for bipolar illness. Biol Psychiatry. 1995;37:235-44.

10. El-Mallakh RS, Li R. Is the Na+-K+-ATPase the link between phosphoinositide metabolism and bipolar disorder? J Neuropsychiatry Clin Neurosci. 1993;5:361-8.

11. Goldstein I, Levy T, Galili D, Ovadia H, Yirmiya R, Rosen H, et al. Involvement of $\mathrm{Na}(+), \mathrm{K}(+)$-ATPase and endogenous digitalis-like compounds in depressive disorders Biol Psychiatry. 2006;60:491-9.

12. Goldstein I, Lerer E, Laiba E, Mallet J, Mujaheed M, Laurent C, et al. Association between sodium- and potassium-activated adenosine triphosphatase alpha isoforms and bipolar disorders. Biol Psychiatry. 2009;65:985-91.

13. Post RM. Role of BDNF in bipolar and unipolar disorder: clinical and theoretical implications. J Psychiatr Res. 2007;41:979-90.

14. Strakowski SM, Delbello MP, Adler CM. The functional neuroanatomy of bipolar disorder: a review of neuroimaging findings. Mol Psychiatry. 2005;10:105-16.

15. Cotman CW, Berchtold NC. Exercise: a behavioral intervention to enhance brain health and plasticity. Trends Neurosci. 2002;25:295-301.

16. Machado-Vieira R, Dietrich MO, Leke R, Cereser VH, Zanatto V, Kapczinski F, et al. Decreased plasma brain derived neurotrophic factor levels in unmedicated bipolar patients during manic episode. Biol Psychiatry. 2007;61:142-4.

17. Kapczinski F, Frey BN, Kauer-Sant'Anna M, Grassi-Oliveira R, Berk M. Brain-derived neurotrophic factor and neuroplasticity in bipolar disorder. Expert Rev Neurother. 2008;8:1101-13.

18. Cunha AB, Frey BN, Andreazza AC, Goi JD, Rosa AR, Goncalves CA, et al. Serum brain-derived neurotrophic factor is decreased in bipolar disorder during depressive and manic episodes. Neurosci Lett. 2006;398:215-9.

19. Gama CS, Andreazza AC, Kunz M, Berk M, Belmonte-de-Abreu PS, Kapczinski F. Serum levels of brain-derived neurotrophic factor in patients with schizophrenia and bipolar disorder. Neurosci Lett. 2007;420:45-8.

20. Monteleone P, Serritella C, Martiadis V, Maj M. Decreased levels of serum brain-derived neurotrophic factor in both depressed and euthymic patients with unipolar depression and in euthymic patients with bipolar I and II disorders. Bipolar Disord. 2008;10:95-100.

21. Tramontina J, Andreazza AC, Kauer-Sant'Anna M, Stertz L, Goi J, Chiarani F, et al. Brain-derived neurotrophic factor serum levels before and after treatment for acute mania. Neurosci Lett. 2009;452:111-3.

22. Decker S, Grider G, Cobb M, Li XP, Huff MO, El-Mallakh RS, et al. Open field is more sensitive than automated activity monitor in documenting ouabain-induced hyperlocomotion in the development of an animal model for bipolar illness. Prog Neuro-Psychopharmacol Biol Psychiatry. 2000;24:455-62.

23. El-Mallakh RS, El-Masri MA, Huff MO, Li XP, Decker S, Levy RS. Intracerebroventricular administration of ouabain as a model of mania in rats. Bipolar Disord. 2003;5:362-5.

24. Ruktanochai DJ, El-Mallakh RS, Li R, Levy RS. Persistent hyperactivity following a single intracerebroventricular dose of ouabain. Physiol Behav. 1998;63:403-6.

25. Riegel RE, Valvassori SS, Elias G, Réus GZ, Steckert AV, De Souza B, et al. Animal model of mania induced by ouabain: evidence of oxidative stress in submitochondrial particles of the rat brain. Neurochem Int. 2009;55:491-5.

26. Frey BN, Andreazza AC, Ceresér KM, Martins MR, Valvassori SS, Réus GZ, et al. Effects of mood stabilizers on hippocampus BDNF levels in an animal model of mania. Life Sci. 2006;79:281-6.

27. Hamid H, Gao Y, Lei Z, Hougland MT, El-Mallakh RS. Effect of ouabain on sodium pump alpha-isoform expression in an animal model of mania. Prog Neuropsychopharmacol Biol Psychiatry. 2009;33:1103-6.

28. Nesher M, Shpolansky U, Rosen H, Lichtstein D. The digitalis-like steroid hormones: new mechanisms of action and biological significance. Life Sci. 2007;80:2093-107.

29. Riegel RE, Valvassori SS, Moretti M, Ferreira CL, Steckert AV, De Souza $\mathrm{B}$, et al. Administração intracerebroventricular ouabaína induz estresse oxidativo no cérebro de rato. Int J Dev Neurosci. 2010;28(3):233-7.

30. Palomino A, Vallejo-Illarramendi A, González-Pinto A, Aldama A, González-Gómez C, Mosquera F, et al. Decreased levels of plasma BDNF in first-episode schizophrenia and bipolar disorder patients. Schizophr Res. 2006;86:321-2.

31. Gratacos M, Gonzalez JR, Mercader JM, Cid RD, Urretavizcaya M, Estivill X. Brain-derived neurotrophic factor Val66Met and psychiatric disorders: meta-analysis of case-control studies confirm association to substance-related disorders, eating disorders, and schizophrenia. Biol Psychiatry. 2007;61:911-22.

32. Manji HK, Duman RS. Impairments of neuroplasticity and cellular resilience in severe mood disorders: implications for the development of novel therapeutics. Psychopharmacol Bull. 2001;35:45-9.

33. Sheline YI, Wang PW, Gado MH, Csernansky JG, Vannier MW. Hippocampal atrophy in recurrent major depression. Proc Natl Acad Sci. 1996;93:3908-13.

34. Fernandes BS, Gama CS, Walz JC, Ceresér KM, Fries GR, Colpo G, et al. Increased neurotrophin-3 in drug-free subjects with bipolar disorder during manic and depressive episodes. J Psychiatr Res. 2010;44(9):561-5.

35. Walz JC, Magalhães PV, Giglio LM, Cunha AB, Stertz L, Fries GR, et al. Increased serum neurotrophin- $4 / 5$ levels in bipolar disorder. J Psychiatr Res. 2009;43(7):721-3.

36. Barbosa IG, Huguet RB, Neves FS, Reis HJ, Bauer ME, Janka Z, et al. Impaired nerve growth factor homeostasis in patients with bipolar disorder. World J Biol Psychiatry. 2011;12(3):228-32.

37. Banerjee U, Dasgupta A, Rout JK, Singh OP. Effects of lithium therapy on $\mathrm{Na}+\mathrm{K}+$-ATPase activity and lipid peroxidation in bipolar disorder. Prog Neuropsychopharmacol Biol Psychiatry. 2012;37(1):56-61.

38. Kapczinski F, Dal-Pizzol F, Teixeira AL, Magalhães PV, Kauer-Sant'Anna $\mathrm{M}$, Klamt F, et al. Peripheral biomarkers and illness activity in bipolar disorder. J Psychiatr Res. 2011;45(2):156-61. 